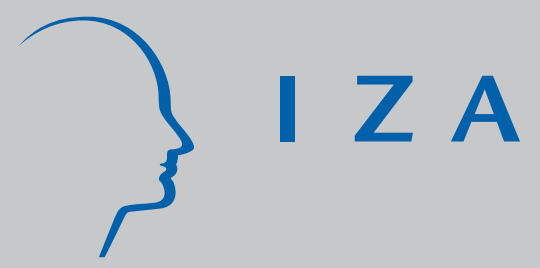

IZA DP No. 479

Unions and Employment Growth: The One Constant?

J ohn T. Addison

Clive R. Belfield

April 2002 


\title{
Unions and Employment Growth: The One Constant?
}

\author{
John T. Addison \\ Moore School of Business, University of South Carolina and IZA, Bonn \\ Clive R. Belfield \\ Teachers College, Columbia University
}

\author{
Discussion Paper No. 479 \\ April 2002
}

\author{
IZA \\ P.O. Box 7240 \\ D-53072 Bonn \\ Germany \\ Tel.: +49-228-3894-0 \\ Fax: +49-228-3894-210 \\ Email: iza@iza.org
}

This Discussion Paper is issued within the framework of IZA's research area Mobility and Flexibility of Labor. Any opinions expressed here are those of the author(s) and not those of the institute. Research disseminated by IZA may include views on policy, but the institute itself takes no institutional policy positions.

The Institute for the Study of Labor (IZA) in Bonn is a local and virtual international research center and a place of communication between science, politics and business. IZA is an independent, nonprofit limited liability company (Gesellschaft mit beschränkter Haftung) supported by the Deutsche Post AG. The center is associated with the University of Bonn and offers a stimulating research environment through its research networks, research support, and visitors and doctoral programs. IZA engages in (i) original and internationally competitive research in all fields of labor economics, (ii) development of policy concepts, and (iii) dissemination of research results and concepts to the interested public. The current research program deals with (1) mobility and flexibility of labor, (2) internationalization of labor markets, (3) welfare state and labor markets, (4) labor markets in transition countries, (5) the future of labor, (6) evaluation of labor market policies and projects and (7) general labor economics.

IZA Discussion Papers often represent preliminary work and are circulated to encourage discussion. Citation of such a paper should account for its provisional character. A revised version may be available on the IZA website (www.iza.org) or directly from the author. 
IZA Discussion Paper No. 479

April 2002

\section{ABSTRACT}

\section{Unions and Employment Growth: The One Constant?*}

Sequential analyses of the major workplace data sets available to British researchers - the Workplace Industrial/Employee Relations Surveys (WIRS/WERS) - have revealed shifts in some previously solid relationships between union presence and a variety of establishment performance indicators. So much so that it is now conventional to speak of a pronounced reduction in the 'disadvantages of unionism' in that country. One finding that seems to have persisted in cross section, however, is the negative effect of unions on employment growth. Following on a recent study of AWIRS (Wooden and Hawke, 2000), we reexamine the issue using new panel data from the WERS series, where workplaces were surveyed in 1990 and then followed-up in 1998. We report similar evidence of employment retardation in union regimes. Moreover, use of the panel also hints that some other unfavorable union effects may be longer standing than suggested in cross-section work.

JEL Classification: J53

Keywords: panel data, unions, employment growth, labor productivity, financial performance

John T. Addison

Department of Economics

Moore School of Business

University of South Carolina

Columbia, SC 29208

USA

Tel.: +1-803-777-4608

Fax: +1-803-777-6876

Email: ecceaddi@darla.badm.sc.edu

*The authors acknowledge the Department of Trade and Industry, the Advisory, Conciliation and Arbitration Service (ACAS), the Economic and Social Science Research Council, and the Policy Studies Institute (PSI) as originators of the 1998 Workplace Employee Relations Panel Survey, and the Data Archive at the University of Essex as the distributor of the data. None of these organizations bears any responsibility for the authors' analysis and interpretation of the data. 


\section{Introduction}

In an interesting paper published in this Journal, Wooden and Hawke (2000) examine the effects of Australian unions on employment growth between 1989/90 and 1995. Using the Australian counterpart of the British Workplace Industrial Relations Survey (WIRS), they report evidence of unions slowing employment growth by approximately 2.5 percentage points a year. As they note, this value is similar to that obtained by Blanchflower et al. (1992) using the British WIRS for 1984 - and, for that matter, close to U.S. findings reported by Leonard (1992) using Californian manufacturing plant data.

Yet analysis of sequential workplace surveys in Britain has revealed that many of adverse effects of unions on establishment performance observed in the 1980s have not survived through time. At the price of some imprecision, cases in point include union impact on financial performance, levels of and changes in labor productivity, and even wages (the evidence is reviewed in Addison and Belfield, 2002). The same obtains for 'industrial relations' variables such as the climate of the workplace (Addison and Belfield, 2001). ${ }^{1}$ It is conventional to ascribe such changes - widely referred to in Britain as a 'reduction in the disadvantages of unionism' - to legislation introduced between 1980 and 1993 removing union immunities under the law, inter al. One seeming constant in all of this, however, is the negative effect of unionism on employment growth. That is to say, all studies continue to point to slowed employment growth in union regimes (e.g. Fernie and Metcalf, 1995; Booth and McCulloch, 1999; Addison and Belfield, 2001).

Since the employment findings have a basis in cross-section data, it is of no small interest to see if this retardation holds up in panel data rather than a point-in-time cross section, where past employment is measured retrospectively. Our primary goal is therefore to subject the employment growth result to closer scrutiny. In this endeavor, we shall replicate Wooden and Hawke, including 
their useful innovation of substituting average employment over the sample period for base period employment in calculating employment change. Equally, it no less relevant to determine - within the limits of the new British data - whether use of the panel provides insights into union effects on outcome indicators other than employment. Accordingly, in this replication we shall also have occasion to range a little further afield.

The organization of the paper is as follows. We first discuss the data set, noting its strengths and limitations for the purposes at hand. Second, we initially present our replication of Wooden and Hawke before proceeding to offer a preferred measure of the union variable for Britain, substituting union recognition for union membership/density and also charting the effects of changes in collective bargaining status. Third, we provide an addendum that reflects British preoccupations with observed changes in union impact that have been observed in repeated cross sections. Specifically, using the same methodological approach, we examine the association between unionism and two other important outcome indicators, namely, changes in labor productivity and financial performance. A brief interpretative section concludes.

\section{The Data}

The dataset used here is a panel survey of workplaces in existence in 1990 and in 1998, namely, the 1998 Workplace Employee Relations Panel Survey (WER-PS). The base period workplaces were a size-stratified random sample of approximately one-half the 2,061 establishments contained in the 1990 Workplace Industrial Relations Survey. Workplaces still in existence were re-surveyed in $1998 .^{2}$ The WER-PS excludes workplaces with fewer than 25 employees, but covers all sectors of the U.K. economy other than agriculture. In the questionnaire, managers are asked to respond on issues dealing with matters such as management organization, 
unionization, and systems of worker consultation and communication. The final sample comprises 846 workplaces, a response rate of 85 percent of those workplaces surviving to 1998 . Because of missing responses across the workplaces, however, our final sample is 496 workplaces. As response bias was correlated with size, sampling weights are applied throughout this analysis (for further details, see Millward et al., 2000). Both by design and in actuality, the WER-PS closely resembles the AWIRS panel component analysed by Wooden and Hawke (2000).

Panel data offer a number of advantages over their cross-section counterparts. These include a more accurate assessment of workplace characteristics, and clearer identification of fixed and varying workplace conditions. In addition, the 1990 and 1998 questionnaires were harmonized, reducing the possibility of measurement error and misclassification of practices (although the phraseology for some questions in the 1998 follow-up - albeit intended to measure the same phenomena - does differ from that for the original questions in 1990).

Yet these panel data are subject to a number of caveats. First, the survey only pertains to surviving firms, and so does not identify relationships for the entire U.K. economy. Also, by definition the surviving firms have not experienced the sharpest falls in employment - to zero - and so panel data may underestimate the impact of key variables on employment growth (specifically, differences in death rates between union and nonunion firms, see Addison et al., 2001). Second, although differencing may absorb heterogeneity, it does not explain it. Key relationships may in fact be obscured because the largest proportion of variation in employment growth may be in variables that are not observable using panel data. Third, causality may not be isolated. Establishments in quest of profit maximization, which we can equate with positive changes in employment, may either adopt or drop certain workplace practices. (Partly in recognition that other outcome variables may be better indicators of the maximand than unemployment, we also examine 
the association between unionism and labor productivity and financial performance.) Establishments that discontinue a given practice presumably expect this to boost performance; yet other firms that adopt the same practice may have the same expectation. This 'endogeneity of change' reduces the explanatory power of standard panel estimation, and may produce the curious result that workplaces that discontinue a practice have better outcomes, but so too do those firms that adopt the same practice. Fourth, the incidence of practices in the initial and later periods should ideally be considered: if a given practice is common in the initial period, then subsequent adopters may in fact be providing evidence on the consequences of 'late' adoption within the economy as a whole. Finally, the optimal interval between survey and follow-up cannot be easily predicted: if the interval is too long, other elements may not be assumed to be held constant; if it is too short, the likelihood of a substantive impact from any workplace change is reduced. For all these reasons panel data are not a panacea. That said, they do represent a valuable source for verifying the robust results found in cross-sectional analyses.

\section{(Table 1 near here)}

Table 1 corresponds to Table 1 in Wooden and Hawke (2000, 94). Workplaces are crossclassified by workplace employment levels in the base and terminal periods. It can be seen that, between 1990 and 1998, 56 percent of U.K. workplaces experienced falling employment levels; just 11.5 percent grew by more than one half their original size. Workplace size and organization status appear to be correlated with employment growth: larger establishments were more likely to have sharp declines in employment and private-sector plants grew at a slower rate than their publicsector counterparts (although in the Australian case, the private sector grew faster between 1989/1990 and 1995). The bottom two panels of the table show that unionization and employment change are correlated. Union density is the measure used by Wooden and Hawke (2000): whereas 
18.0 percent of zero-density workplaces grew in employment by more than one half, only 6.1 percent of workplaces where density exceeds 75 percent did so. An alternative measure of unionization exploited here is whether or not the workplace has a union that is recognized for collective bargaining purposes; this will be our preferred measure for the U.K. economy. But the conclusion is unchanged. Whereas employment rose by more than one half in 16.5 percent of nonunion workplaces, only 7.1 percent of union workplaces experienced such growth. Although the correlations have the same sign for both the British and the Australian economies, the results for the former show a clearer tendency for unionization and employment growth to be negatively related.

These correlations will be subsequently tested in a reduced-form OLS estimation, with employment growth as the dependent variable. Here we pause to note that Wooden and Hawke $(2000,95)$ calculate employment growth in two ways. In each case, the numerator is terminal period employment less base period employment. In one approach (following the conventional method), the denominator is base period employment; in the other (their preferred approach), the denominator is the average of base and terminal period employment. Descriptive statistics for both growth measures for the U.K. are given in Table 2. Whereas the conventional measure shows the average firm grew, the preferred measure shows negative employment growth among these survivor workplaces, at 16.6 percent (regression to the mean). As for Wooden and Hawke, however, note that the latter measure has desirable properties for OLS estimation: skewness is low, and kurtosis is close to 3. Accordingly, it is used as the dependent variable in the estimations.

\section{(Table 2 near here)}

In the initial set of estimations, the determinants of employment growth were constructed to match as closely as possible those of Wooden and Hawke. ${ }^{3}$ Descriptive statistics for the 
independent variables are given in Table 3. The independent variables include: employment in the base period; workplace autonomy in the base period; change in autonomy between 1990 and 1998; single-workplace organization; head office status; participation in international markets; sector; and whether the firm merged or changed location between the base and terminal periods. A range of alternative specifications was modelled, using variables for occupational mix, establishment age, organizational size, and industry type. These variables were also used by Wooden and Hawke. In addition, both weighted and unweighted estimations were performed. (Because the weights are partly constructed based on workplace size, which is correlated with unionization, removing the weights does alter the results somewhat. However, only the weighted results are formally reported here to achieve consistency with other research.) In sum, the initial estimation tracks that in Table 4 of Wooden and Hawke $(2000,100)$ as closely as possible, even if differences in time period and economic conditions between the U.K. and Australia suggest caution in juxtaposing the results.

\section{(Table 3 near here)}

Based on differences in economic conditions between the two countries, however, a preferred empirical model is also introduced for the U.K. economy. This preferred model includes control variables that were found to be significant in the British case (namely, industry and age), and it uses a different measure of unionization. Descriptive statistics for the new union measures are reported at the base of Table 3. The WER-PS includes a variable indicating whether or not the workplace recognizes a union for collective bargaining purposes: from this perspective, 54 percent of workplaces were unionized in 1990, and 57 percent were unionized in 1998. From the panel data, it is possible to identify the 49 percent of workplaces that had a union in both 1990 and 1998 , the 5 percent that abandoned a union, the 8 percent that introduced one, and the 38 percent of 
workplaces without unionism throughout. Both the variables for union recognition in 1990 and the change in union recognition, 1990-98, are used in the second set of estimations.

\section{Results for Employment Change}

Results for OLS estimation of employment growth are reported in Table 4 for the total sample of establishments and for the private and public sectors separately. As noted earlier, these specifications are designed to follow those of Wooden and Hawke as closely as possible. Column (1) of the table provides results for the most parsimonious specification that in addition to the two union measures - union presence (here nonzero density) and union density - includes just employment size in 1990, mergers subsequent to 1990, and changes in location. It can be seen that, at this level of aggregation at least, neither union measure has any discernible impact on employment growth. ${ }^{4}$ As expected, larger establishments grow less/contract more than their smaller counterparts. Not consistent with Wooden and Hawke, however, is the positive influence of changes in location on the outcome indicator, while the relation between merger activity and employment change is negative (albeit not significantly so) rather than positive and statistically significant as in the Australian case.

\section{(Table 4 near here)}

Column (2) reports a more detailed specification. The statistical insignificance of the union measures is again apparent. Of the new variables, local workplace autonomy has a positive and (marginally) statistically significant impact on employment growth - as for Wooden and Hawke but in our sample this does not extend to changes leading to greater workplace autonomy. There is also the suggestion that workplaces that are designated as head offices grow faster than other establishments, but the association is weak. Neither exposure to international products markets nor private sector status appears to have any material effect on employment change. (In the latter 
context, note that WER-PS does not allow us to identify public sector commercial enterprises and so the omitted category is the public sector as a whole).

The remainder of Table 4 provides separate results for the private and public sectors. There are few surprises. That is to say, the union variables remain statistically insignificant and few differences between sector are found. ${ }^{5}$ The exception is the deunionization variable: in private sector establishments where union membership fell to zero between 1990 and 1998 employment rose. No such positive outcome is found for the public sector. Other findings of potential interest are the positive effect of international competition on private sector employment change and an indication that workplace autonomy (although again in levels rather than change form) is seemingly beneficial for public sector establishments.

In one sense, and abstracting from the findings from estimates using unweighted data, these are disappointing results. At issue, however, is the suitability of Wooden and Hawke's union variables for the British case. This is most telling in the case of the union measure that simply charts the presence of any union member (i.e. the union measure). Wooden and Hawke take pains to justify this variable in the Australian case. They argue that very low rates of unionization may stimulate managers to introduce improved human relations practices that at once forestall the union threat and improve employment (although the latter association is not tested), whereas a total absence of unionization at the workplace implies no "union threat" and no such employmentaugmenting practices. No such institutional parallel/constraint would seem to apply in the case of the U.K. Indeed, as a practical matter, the bulk of the British literature has eschewed use of their second union variable - namely, union density - and has instead favored union recognition for collective bargaining purposes over union density to proxy union bargaining power. Reflecting the different industrial relations milieu of the U.K., therefore, we next report results for specifications 
that substitute union recognition for union density, while simply omitting the variable indicating the presence of any union members. In addition, we explore possible asymmetries in union effect and also look to duration effects of the union institution. To these ends, we split the union recognition dummy into four combinations. Specifically, we identify circumstances where the workplace never had a union, had a union throughout, and introduced or abandoned a union. Furthermore, we select a modestly expanded set of controls, where these proved incrementally significant. The results of this exercise are provided in Table 5.

\section{(Table 5 near here)}

Beginning with the results for the moment-in-time, base period union recognition variable, it can be seen that for both the total sample and its private and public sector components, union recognition is associated with sharply reduced employment growth (see columns (7), (9), and (11) of the table). The absolute value of the union effect is stronger for the private sector than for the public sector, but the difference is not statistically significant. The point estimates imply that, other things being equal, private (public) sector plants that recognized unions in 1990 had 23.5 (10.6) percent lower employment growth in the next 8 years than their union-free counterparts.

But looking behind these results (i.e. taking account of directional movements in union recognition status over the sample period), it appears that long-standing unionism is the culprit (see columns (8), (10), and (12) of the table). Both in aggregate and across both sectors, establishments that recognized unions in the base period and the terminal period experienced even sharper employment falls than observed earlier: 28.9 percent in the private sector and 18.4 percent in the public sector. Again, the difference in the effect of (long-standing) unions is not statistically different as between sectors. There is no evidence of symmetry in union effect in the private sector. That is to say, establishments that recognized unions in 1990 but not 1998 and those recognizing 
unions in 1998 but not 1990 each saw reductions in employment vis-à-vis union-free establishments. Only in the public sector is there evidence of symmetry: plants in which unions were no longer recognized in 1998 grew faster and establishments newly recognizing unions grew slower.

Progressively, we have obtained results that more closely approximate those of Wooden and Hawke. That is to say, unions do seem to retard employment growth. But, unlike the Australian case, they seem to have this effect in both sectors, even if the effects appear less pronounced in the public sector. On closer inspection, the effects of long-standing unionism are more similar between sectors. Differences between sectors seem ultimately to have more to do with the effects of innovations, namely, changes in recognition in both directions.

\section{An Extension: Labor Productivity and Financial Performance}

Given the robustness of the union recognition results, it is appealing to investigate whether other cross-sectional relationships are supported by the panel data. As was noted earlier, many U.K. cross-section studies have identified adverse effects of unions on labor productivity and on financial performance. For labor productivity, early studies point unequivocally to lower productivity in unionized establishments, but by the same token it is widely reported that such plants increased their productivity more during the late 1980s (e.g. Gregg et al., 1993). By the late 1990s there are even indications that the labor productivity gap of union plants may have been eliminated (Addison and Belfield, 2001; Conyon and Freeman, 2001). That said, with few exceptions (Moreton, 1999), evidence of a positive union productivity differential is not observed.

Research findings pertaining to union impact on profitability are arguably more mixed, although inherently less conclusive (see below). Thus, for example, Menezes-Filho (1997) and 
Conyon and Freeman (2001) report statistically significant negative coefficient estimates for the union recognition variable throughout, while Booth and McCulloch (1999) find evidence of better financial performance in the generality of workplaces that recognize unions. It appears that the profitability results are rather sensitive to union type, with some studies indicting nonmanual unions, others the closed shop, and yet others multiple unionism as the culprit (see Addison and Belfield, 2002). That said, there is more agreement on a decline in negative union effects over time and, if results from the most recent cross-section WERS for 1998 are to be believed, no obvious indication of impaired profitability in union plants (Addison and Belfield, 2001).

Using panel data to investigate relationships other than employment growth may be expected to shed some light on the employment growth results. Most obviously perhaps, negative effects of unionism on labor productivity if observed would suggest that the differential reduction of employment in the union sector cannot be interpreted as an efficiency response - as might accrue from an elimination of employment protective practices. By the same token, since the expression of union voice can be a pro-productive activity, detection of beneficial union productivity effects would call into question the assumption of an employment growth maximand. As far as financial performance is concerned, the theoretical picture is more clouded. Lower profitability in unionized plants may of course represent an efficiency-neutral transfer of excess profits. More generally, union rent-seeking behavior is quite compatible with maximization of the joint surplus in (static) efficient bargaining models. In the long run, however, investment in physical and intangible capital may fall and presumably with it sales and employment (unless unions inhibit reductions in force). And any favorable effects of unions on financial performance might not lead to employment growth if the former are generated by removal of restrictive practices. Despite these conceptual 
difficulties, consideration of union impact on all three dimensions of performance should assist in the attribution of causality.

Two pertinent performance indicators are available from the WER-PS. These are based on the subjective responses of managers to the questions: "How does the level of labor productivity here compare with other similar workplaces?" and "How would you assess the financial performance of this establishment compared with other establishments in the same industry?" These questions were asked in both 1990 and 1998. Note that for the financial performance measure, this question is only appropriate for 213 trading workplaces.

\section{(Table 6 near here)}

Categorical dependent variables were constructed based on the difference in the responses to these questions between 1990 and 1998. The frequencies are reported in Table 6. Comparing 1998 with 1990, 10.7 percent of the 496 workplaces recorded relatively higher labor productivity, 32.1 percent recorded the same relative position, and 57.3 percent recorded a relative fall in labor productivity. For the much reduced sample reporting financial performance, the situation is more positive, with 23.0 percent of establishments recording improved relative performance and a little less than that proportion recording worse outcomes. For each new performance indicator, our dependent variable will assume the value of 0 if there was no change across the period, -1 if there was a deterioration, and +1 if there was an improvement. As for the employment equations, three sets of union measures are investigated in the new performance equations, while the other regressors match those previously.

Ordered probit estimations for the labor productivity indicator are reported in columns (1) through (3) of Table 7. Column (1) of the table provides results for the two union measures selected by Wooden and Hawke: the presence of any union member and union density. As can be seen, 
neither coefficient estimate is statistically significant. However, in both columns (2) and (3) there is evidence to suggest that unions have a negative effect on labor productivity once we substitute the recognition measure for density. Recognized unions as of 1990 are associated with reductions in recorded productivity (column (2)). This result appears to be driven by workplaces where the union was recognized throughout the 8-year period of the panel (column (3)). Moreover, workplaces that abandoned a union are associated with improved labor productivity, offering some corroboration of our earlier findings of adverse union employment effects.

\section{(Table 7 near here)}

Ordered probit results for financial performance are reported in columns (4) through (6) of Table 7. Possibly reflecting smaller sample size - recall that just 213 private- and public-sector plants are trading entities - the results are weaker than those for productivity, but the directional effects are the same. That is to say, the coefficient estimate for union recognition as of the base period is again negative albeit statistically insignificant (column (4)), while workplaces that no longer recognized unions at end of period record marginally significant improvements in financial performance (column (6)).

Yet it may be objected that the index measures used in the above exercise are difficult to interpret. In particular, note that an establishment reporting, say, high relative labor productivity in 1990 but average productivity in 1998 would be scored -1, whereas a plant reporting low productivity in both periods would be scored 0 . Although the advantage of panel data is that they allow us to relate changes in workplace representation (inter al.) to changes in outcomes, the relationships may differ according to starting point.

In recognition of this problem, the samples were stratified according to the initial levels labor productivity and financial performance reported for the base period. ${ }^{6}$ That is, the equations in 
columns (2)/(3) and (5)/(6) of Table 7 were reestimated according to the performance situation as of 1990. In each case, separate regressions were run for (a) plants that reported relatively high levels of performance and (b) establishments that reported only average or low levels of performance. Even though these separate equations have small sample sizes, with unsatisfactory diagnostic statistics, they nowhere undermine the results presented earlier. The counterparts of the estimations in columns (2) and (5) of Table 7 indicate that labor productivity is reduced by union recognition among the high productivity group of plants if not for lower productivity sample; for financial performance, no statistically significant results are found. The counterparts of the estimations in columns (3) and (6) of Table 7 yield results that are congruent with our main argument. Specifically, for those workplaces with relatively high initial labor productivity, maintaining union recognition in 1990 and 1998 impaired productivity; for those with relatively low labor productivity, the union coefficients were statistically insignificant thoughout. For workplaces with superior financial performance, the union recognition coefficient estimates were all statistically insignificant; but for those with lesser financial performance, abandoning a union raised performance while maintaining union recognition in 1990 and 1998 impaired performance. (Full details of these estimations are available from the authors on request.)

The bottom line would appear to be that union recognition is associated with lower labor productivity and reduced financial performance after all. To this extent, the employment effects are not the only 'constant' or empirical regularity when we consider panel data. More importantly, however, the findings for the new outcome indicators are prima facie consistent with the employment results. 


\section{Conclusions}

The negative relationship between unions and employment growth previously observed in cross section is robust to the use of panel data. Wooden and Hawke's (2000) results for Australia can now be extended to the U.K. for the period 1990 to 1998. Using first-difference data, we were able to control for firm-level heterogeneity in ways not possible with cross-sectional WIRS/WERS data and so explore in more detail what drives this relationship. Specifically, we teased out asymmetries between maintenance, adoption and abandonment of union status: firms that maintained unions fared worst, with those that abandoned unions boosting their employment levels.

In addition, we explored additional outcome measures for our sample of U.K. workplaces that lasted at least eight years, namely, labor productivity and financial performance. The results are less conclusive than for employment growth but they are generally corroborative of the latter. Workplaces with long-lived unions report weakening labor productivity, and workplaces that abandon a union report improvements in labor productivity and financial performance. To this extent we can also tentatively conclude that negative union effects on employment growth are not the only constant in the British workplace data after all. 


\section{ENDNOTES}

1. One fascinating contrary tendency in the data is the emergence in the 1990s of a statistically significant (positive) association between all union measures of union presence and plant closings, where none was observed in the 1980s. For two different interpretations of this change, see Addison et al., 2001; Bryson, 2001.

2. The WER-PS panel survey cannot be linked to the two contemporaneous cross-sectional surveys: the 1990 Workplace Industrial Relations Survey was by design separated from the panel survey, while the 1998 Workplace Employee Relations Survey of 1998 is an entirely separate entity.

3. Unfortunately we were unable to construct demand variables from the WER-PS. Only the crosssection WIRS/WERS contain measures identifying increasing or decreases in sales and then only for the 12 months preceding the survey event.

4. For regressions using unweighted data, however, the effect of union density is well determined. The coefficient estimate is -0.338 and a standard error of 0.099 , implying that a workplace with the mean density of 43.97 percent would have experienced a rate of employment growth, 1990-98, that was 14.8 percentage points less than an otherwise comparable establishment with (almost) no union workers. This translates into a diminution in employment growth of roughly 1.8 percentage points a year. (For AWIRS, as we have seen, the corresponding reduction reported by Wooden and Hawke is 2.5 percentage points a year, using weighted data). For the WER-PS, the use of unweighted data consistently yields more adverse union employment effects than the weighted data. Results are available from the authors on request.

5. Again, results from unweighted data seemingly flag differences in union impact between sectors. For the private sector, it is the presence of (any) union members that retards employment growth whereas for the public sector it is union density that counts.

6. We also re-ran the performance equations for specifications in which initial levels of labor productivity and financial performance entered as additional arguments. The results were unimpressive, reflecting the correlation between initial levels and changes in levels of these variables 


\section{REFERENCES}

Addison, John. T., and Clive R. Belfield. 2001. "Updating the Determinants of Firm Performance: Estimation Using the 1998 U.K. Workplace Employee Relations Survey." British Journal of Industrial Relations 39 (September): 341-66.

Addison, John T., and Clive R. Belfield. 2002. "Unions and Establishment Performance: Evidence from the British Industrial/Employee Relations Surveys." Discussion Paper No. 455, Institute for the Study of Labor/IZA, Bonn.

Addison, John T., John Heywood, and Xiangdong Wei. 2001. "Unions and Plant Closings in Britain: New Evidence from the WERS Panel." Unpublished paper, Department of Economics, University of South Carolina.

Blanchflower, David G., Neil Millward, and Andrew J. Oswald. 1992. "Unionism and Employment Behaviour." Economic Journal 101 (July): 815-34.

Booth, Alison L., and Andrew McCulloch. 1999. "Redundancy Pay, Unions and Employment." Manchester School 67 (June): 346-66.

Bryson, Alex. 2001. "Unions and Workplace Closure in Britain, 1900-1998." Unpublished paper, Policy Studies Institute.

Conyon, Martin J., and Richard B. Freeman. 2001. "Shared Modes of Compensation and Firm Performance: U.K. Evidence." Working Paper 8448, National Bureau of Economic Research.

Fernie, Sue, and David Metcalf. 1995. "Participation, Contingent Pay, Representation and Workplace Performance: Evidence from Great Britain." British Journal of Industrial Relations 33 (September): 379-415.

Gregg, Paul, Stephen Machin, and David Metcalf. 1993. "Signals and Cycles? Productivity Growth and Changes in Union Status in British Companies, 1984-9." Economic Journal 108 (July): 894-907.

Leonard, Jonathan S. 1992. "Unions and Employment Growth." Industrial Relations 33 (October): $80-94$.

Menezes-Filho, Naercio. 1997. "Unions and Profitability over the 1980s: Some Evidence on UnionFirm Bargaining in the United Kingdom." Economic Journal 107 (May): 651-670.

Millward, N., Bryson, J., Forth, S. 2000. All Change At Work (Routledge, London). 
Moreton, David. 1999. "A Model of Labor Productivity and Union Density in British Private Sector Unionized Establishments." Oxford Economic Papers 51 (April): 322-344.

Wooden, Mark, and Anne Hawke. 2000. "Unions and Employment Growth: Panel Data Evidence." Industrial Relations 39 (January): 88-107. 
TABLE 1

EMPLOYMENT GROWTH OF WORKPLACES, 1990-98, BY WORKPLACE CHARACTERISTICS

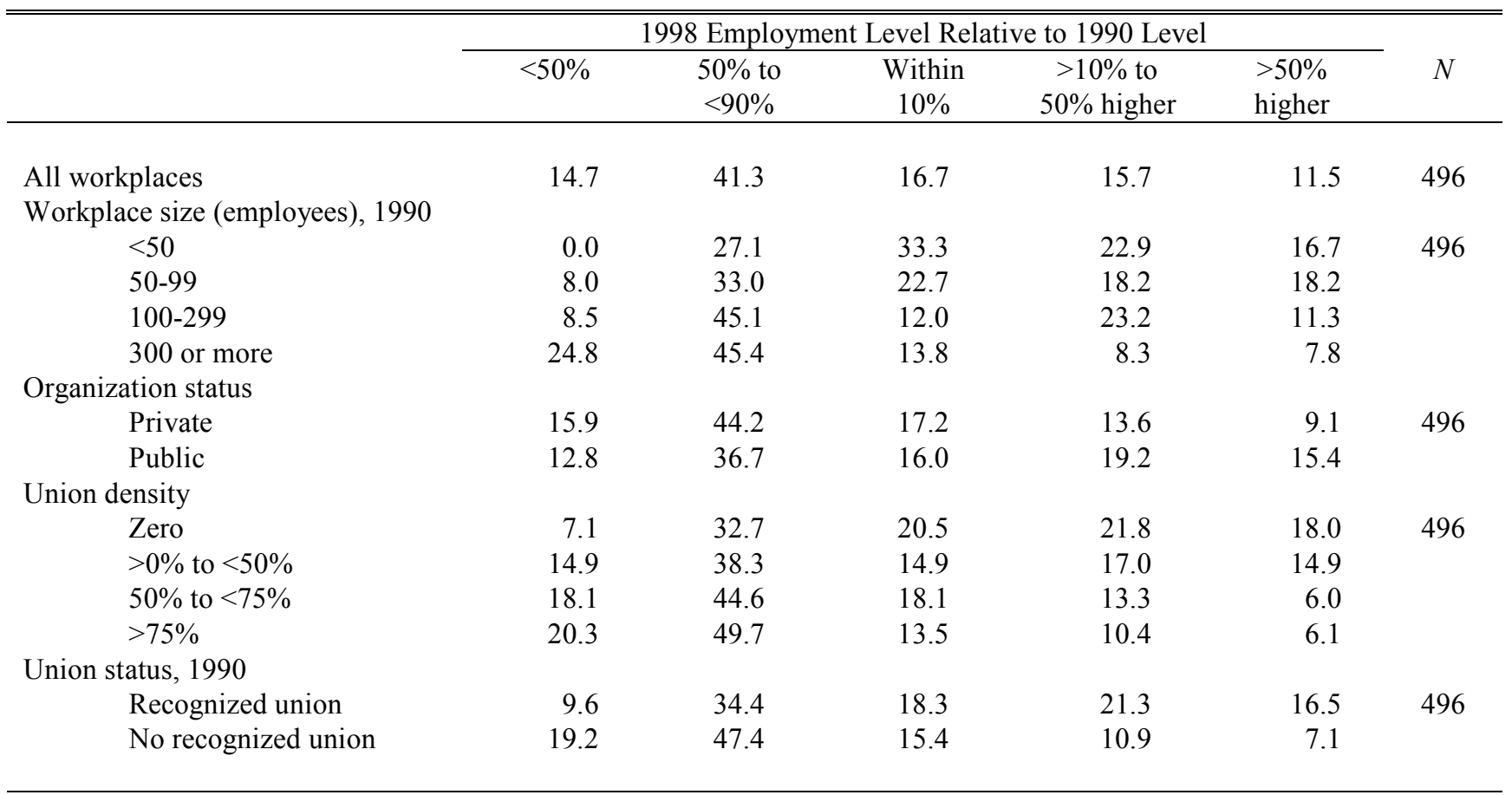

NOTE: Data proportions are unweighted.

SOURCE: 1998 Workplace Employee Relations Panel Survey. 
TABLE 2

EMPLOYMENT GROWTH MEASURES: DESCRIPTIVE STATISTICS

\begin{tabular}{|c|c|c|}
\hline $\begin{array}{l}\text { Descriptive } \\
\text { Statistic }\end{array}$ & $\begin{array}{l}\text { Conventional Growth Measure } \\
\qquad\left(E_{98}-E_{90}\right) /\left(E_{90} \times 100\right)\end{array}$ & $\begin{array}{c}\text { Preferred Growth Measure } \\
\left(E_{98}-E_{90}\right) /\left[\left(\left(E_{90}+E_{98}\right) / 2\right) \times 100\right]\end{array}$ \\
\hline Mean & 4.59 & -16.56 \\
\hline Standard Deviation & 124.58 & 53.81 \\
\hline Skewness & 11.67 & 0.13 \\
\hline Kurtosis & 192.01 & 4.05 \\
\hline
\end{tabular}

NOTE: Data proportions are unweighted.

SOURCE: 1998 Workplace Employee Relations Panel Survey. 
TABLE 3

EXPLANATORY VARIABLES: DESCRIPTIONS AND SUMMARY STATISTICS

\begin{tabular}{|c|c|c|c|c|}
\hline \multirow[t]{2}{*}{ Variable Name } & \multirow[t]{2}{*}{ Description } & \multicolumn{3}{|c|}{ Mean (SD) } \\
\hline & & Total Sample & Private Sector & Public Sector \\
\hline Employment size in 1990 & $\begin{array}{l}\text { Number of employees at the } \\
\text { workplace in } 1990\end{array}$ & $\begin{array}{r}571.02 \\
(891.89)\end{array}$ & $\begin{array}{r}498.87 \\
(907.52)\end{array}$ & $\begin{array}{r}615.06 \\
(880.79)\end{array}$ \\
\hline Union & $\begin{array}{l}\text { A dummy variable for workplaces } \\
\text { where in } 1990 \text { any union } \\
\text { members were present }\end{array}$ & $\begin{array}{r}0.69 \\
(0.46)\end{array}$ & $\begin{array}{r}0.63 \\
(0.48)\end{array}$ & $\begin{array}{r}0.72 \\
(0.45)\end{array}$ \\
\hline Union density & $\begin{array}{l}\text { Union members in } 1990 \text { as a } \\
\text { percentage of total } \\
\text { employment in } 1990\end{array}$ & $\begin{array}{r}43.97 \\
(38.43)\end{array}$ & $\begin{array}{r}36.43 \\
(35.95)\end{array}$ & $\begin{array}{r}48.57 \\
(39.21)\end{array}$ \\
\hline Deunionized & $\begin{array}{l}\text { A dummy variable for workplaces } \\
\text { where union membership fell } \\
\text { to zero from } 1990 \text { to } 1998\end{array}$ & $\begin{array}{r}0.04 \\
(0.19)\end{array}$ & $\begin{array}{r}0.05 \\
(0.21)\end{array}$ & $\begin{array}{r}0.03 \\
(0.17)\end{array}$ \\
\hline Autonomy & $\begin{array}{l}\text { A dummy variable indicating } \\
\text { decisions are made at this } \\
\text { workplace in } 1990\end{array}$ & $\begin{array}{r}0.36 \\
(0.48)\end{array}$ & $\begin{array}{r}0.38 \\
(0.49)\end{array}$ & $\begin{array}{r}0.35 \\
(0.41)\end{array}$ \\
\hline Change in autonomy & $\begin{array}{l}\text { A variable where } 1 \text { equals more } \\
\text { autonomy, } 0 \text { equals same } \\
\text { autonomy, }-1 \text { equals less } \\
\text { autonomy between } 1990 \text { - } \\
1998\end{array}$ & $\begin{array}{r}-0.03 \\
(0.59)\end{array}$ & $\begin{array}{r}-0.04 \\
(0.55)\end{array}$ & $\begin{array}{l}-0.03 \\
(0.62)\end{array}$ \\
\hline $\begin{array}{l}\text { Single-workplace } \\
\text { organization }\end{array}$ & $\begin{array}{l}\text { A dummy variable for single- } \\
\text { workplace organizations in } \\
1990\end{array}$ & $\begin{array}{r}0.13 \\
(0.34)\end{array}$ & $\begin{array}{r}0.23 \\
(0.42)\end{array}$ & $\begin{array}{r}0.06 \\
(0.24)\end{array}$ \\
\hline Head Office & $\begin{array}{l}\text { A dummy variable for workplaces } \\
\text { that were also the } \\
\text { organization's head office in } \\
1990\end{array}$ & $\begin{array}{r}0.04 \\
(0.20)\end{array}$ & $\begin{array}{r}0.04 \\
(0.19)\end{array}$ & $\begin{array}{r}0.05 \\
(0.21)\end{array}$ \\
\hline International market in 1990 & $\begin{array}{l}\text { A dummy variable for workplaces } \\
\text { that faced product market } \\
\text { competition from overseas }\end{array}$ & $\begin{array}{r}0.09 \\
(0.28)\end{array}$ & $\begin{array}{r}0.12 \\
(0.32)\end{array}$ & $\begin{array}{r}0.00 \\
(1.00)\end{array}$ \\
\hline Private sector & $\begin{array}{l}\text { A dummy variable for workplaces } \\
\text { that were part of a private } \\
\text { sector enterprise }\end{array}$ & $\begin{array}{r}0.38 \\
(0.49)\end{array}$ & $\begin{array}{r}1.00 \\
(0.00)\end{array}$ & $\begin{array}{r}0.00 \\
(0.00)\end{array}$ \\
\hline Merger & $\begin{array}{l}\text { A dummy variable for workplaces } \\
\text { that had merged with other } \\
\text { workplaces or changed } \\
\text { ownership since } 1990\end{array}$ & $\begin{array}{r}0.20 \\
(0.40)\end{array}$ & $\begin{array}{r}0.19 \\
(0.39)\end{array}$ & $\begin{array}{r}0.21 \\
(0.41)\end{array}$ \\
\hline Changed location & $\begin{array}{l}\text { A dummy variable for workplaces } \\
\text { that had changed address since } \\
1990\end{array}$ & $\begin{array}{r}0.10 \\
(0.30)\end{array}$ & $\begin{array}{r}0.10 \\
(0.30)\end{array}$ & $\begin{array}{r}0.10 \\
(0.30)\end{array}$ \\
\hline $\begin{array}{l}\text { Union recognized for } \\
\text { collective bargaining in } 1990\end{array}$ & $\begin{array}{l}\text { A dummy variable for workplaces } \\
\text { where a union was recognized } \\
\text { for collective bargaining in } \\
1990\end{array}$ & $\begin{array}{r}0.54 \\
(0.50)\end{array}$ & $\begin{array}{r}0.45 \\
(0.50)\end{array}$ & $\begin{array}{r}0.59 \\
(0.49)\end{array}$ \\
\hline $\begin{array}{l}\text { Recognized union: } \\
\text { in 1990; in } 1998\end{array}$ & $\begin{array}{l}\text { A dummy variable for workplaces } \\
\text { where a union was recognized } \\
\text { for collective bargaining in }\end{array}$ & $\begin{array}{r}0.49 \\
(0.50)\end{array}$ & $\begin{array}{r}0.38 \\
(0.49)\end{array}$ & $\begin{array}{r}0.55 \\
(0.50)\end{array}$ \\
\hline
\end{tabular}


Recognized union: in 1990; not in 1998

Recognized union: not in 1990; in 1998

Recognized union: not in 1990, not in 1998
1990 and in 1998

A dummy variable for workplaces where a union was recognized for collective bargaining in 1990 but not in 1998

A dummy variable for workplaces where a union was recognized for collective bargaining not in 1990 but in 1998

A dummy variable for workplaces where a union was recognized for collective bargaining not in 1990 and not in 1998
0.05
0.07

\subsection{8}

0.10

0.38

0.45

496 188 308

NOTES: See Wooden and Hawke (Table 3). Data proportions are unweighted. Variables not available using WER-PS 98 are: demand changes; public commercial; definitional change; and separate variables for exporter/importer.

SOURCE: 1998 Workplace Employee Relations Panel Survey. 
TABLE 4

EMPLOYMENT GROWTH EQUATIONS (1)-(6): OLS RESULTS

\begin{tabular}{|c|c|c|c|c|c|c|}
\hline & \multicolumn{2}{|c|}{ Total Sample } & \multicolumn{2}{|c|}{ Private Sector } & \multicolumn{2}{|c|}{ Public Sector } \\
\hline & $(1)$ & $(2)$ & (3) & $(4)$ & $(5)$ & $(6)$ \\
\hline Employment size in 1990 & $\begin{array}{c}-0.028^{* * *} \\
(0.006)\end{array}$ & $\begin{array}{c}-0.028 * * * \\
(0.005)\end{array}$ & $\begin{array}{c}-0.051 * * * \\
(0.014)\end{array}$ & $\begin{array}{c}-0.054 * * * \\
(0.015)\end{array}$ & $\begin{array}{c}-0.018 * * * \\
(0.006)\end{array}$ & $\begin{array}{c}-0.018 * * * \\
(0.006)\end{array}$ \\
\hline Union & $\begin{array}{r}-10.820 \\
(8.446)\end{array}$ & $\begin{array}{c}-12.268 \\
(8.993)\end{array}$ & $\begin{array}{c}-19.799 \\
(13.044)\end{array}$ & $\begin{array}{c}-5.220 \\
(13.992)\end{array}$ & $\begin{array}{c}-4.849 \\
(11.090)\end{array}$ & $\begin{array}{c}-4.831 \\
(11.319)\end{array}$ \\
\hline Union density & $\begin{array}{l}-0.133 \\
(0.118)\end{array}$ & $\begin{array}{l}-0.100 \\
(0.125)\end{array}$ & $\begin{array}{c}0.187 \\
(0.195)\end{array}$ & $\begin{array}{l}-0.003 \\
(0.207)\end{array}$ & $\begin{array}{c}-0.291^{*} \\
(0.151)\end{array}$ & $\begin{array}{c}-0.292 \\
(0.154)\end{array}$ \\
\hline Deunionized & & & & $\begin{array}{c}-28.835^{*} \\
(16.729)\end{array}$ & & $\begin{array}{c}-0.060 \\
(24.878)\end{array}$ \\
\hline Merger & $\begin{array}{r}-12.959 \\
(7.959)\end{array}$ & $\begin{array}{c}-9.611 \\
(8.117)\end{array}$ & $\begin{array}{c}-13.796 \\
(17.537)\end{array}$ & $\begin{array}{c}-13.475 \\
(17.353)\end{array}$ & $\begin{array}{c}-3.165 \\
(8.156)\end{array}$ & $\begin{array}{l}-3.166 \\
(8.157)\end{array}$ \\
\hline Changed location & $\begin{array}{c}37.968 * * \\
(15.502)\end{array}$ & $\begin{array}{c}34.677 * * \\
(16.279)\end{array}$ & $\begin{array}{c}42.219 \\
(26.225)\end{array}$ & $\begin{array}{c}41.723 \\
(25.706)\end{array}$ & $\begin{array}{l}29.929 * \\
(16.746)\end{array}$ & $\begin{array}{c}29.928 \\
(16.781)\end{array}$ \\
\hline Autonomy & & $\begin{array}{l}11.259^{*} \\
(6.478)\end{array}$ & $\begin{array}{c}7.490 \\
(11.528)\end{array}$ & $\begin{array}{c}6.664 \\
(11.388)\end{array}$ & $\begin{array}{l}13.012 * \\
(7.399)\end{array}$ & $\begin{array}{l}13.013^{*} \\
(7.411)\end{array}$ \\
\hline Change in autonomy & & $\begin{array}{l}-3.370 \\
(4.695)\end{array}$ & $\begin{array}{c}4.042 \\
(7.883)\end{array}$ & $\begin{array}{c}1.115 \\
(8.335)\end{array}$ & $\begin{array}{c}-7.788 \\
(5.478)\end{array}$ & $\begin{array}{c}-7.787 \\
(5.488)\end{array}$ \\
\hline Single-workplace org. & & $\begin{array}{c}-2.366 \\
(7.893)\end{array}$ & $\begin{array}{c}-6.299 \\
(10.860)\end{array}$ & $\begin{array}{c}-7.347 \\
(10.314)\end{array}$ & $\begin{array}{c}9.200 \\
(11.928)\end{array}$ & $\begin{array}{c}9.203 \\
(12.261)\end{array}$ \\
\hline Head Office & & $\begin{array}{c}23.920^{*} \\
(13.072)\end{array}$ & $\begin{array}{c}24.652 \\
(21.338)\end{array}$ & $\begin{array}{c}18.203 \\
(21.506)\end{array}$ & $\begin{array}{c}24.380 \\
(16.982)\end{array}$ & $\begin{array}{c}24.378 \\
(16.913)\end{array}$ \\
\hline International market & & $\begin{array}{c}12.264 \\
(8.660)\end{array}$ & $\begin{array}{c}22.989 * * \\
(9.863)\end{array}$ & $\begin{array}{c}25.239 * * \\
(10.935)\end{array}$ & & \\
\hline Private sector & & $\begin{array}{l}10.428 \\
(6.670)\end{array}$ & & & & \\
\hline Adj. R-squared & 0.1306 & 0.1813 & 0.1971 & 0.2204 & 0.1890 & 0.1890 \\
\hline $\mathrm{F}(\mathrm{k}, \mathrm{n}-\mathrm{k})$ & 10.65 & 6.56 & 2.64 & 2.69 & 4.96 & 4.49 \\
\hline$N$ & \multicolumn{2}{|c|}{496} & \multicolumn{2}{|c|}{188} & \multicolumn{2}{|c|}{308} \\
\hline
\end{tabular}

NOTES: See Wooden and Hawke (Table 4). Survey weights are applied.

Constant term included in each estimation.

Heteroskedastic consistent standard errors in parentheses.

$*, * *, * * *$ denote statistical significance at the 0.10 level, 0.05 level, 0.01 level.

SOURCE: 1998 Workplace Employee Relations Panel Survey. 
TABLE 5

EMPLOYMENT GROWTH EQUATIONS (1)-(6): OLS RESULTS

\begin{tabular}{|c|c|c|c|c|c|c|}
\hline & \multicolumn{2}{|c|}{ Total Sample } & \multicolumn{2}{|c|}{ Private Sector } & \multicolumn{2}{|c|}{ Public Sector } \\
\hline & (1) & (2) & (3) & (4) & (5) & $(6)$ \\
\hline \multicolumn{7}{|l|}{ Recognized union in } \\
\hline 1990 & $\begin{array}{c}-20.005^{* * *} \\
(6.529)\end{array}$ & & $\begin{array}{c}-23.525 * * \\
(9.427)\end{array}$ & & $\begin{array}{c}-10.649 * * \\
(9.064)\end{array}$ & \\
\hline $\begin{array}{l}\text { Recognized union: } \\
\text { in 1990; in } 1998\end{array}$ & & $\begin{array}{c}-26.931 * * * \\
(7.064)\end{array}$ & & $\begin{array}{c}-28.891^{* *} \\
(11.588)\end{array}$ & & $\begin{array}{c}-18.371 * * \\
(8.935)\end{array}$ \\
\hline $\begin{array}{l}\text { Recognized union: } \\
\text { in 1990; not in } 1998\end{array}$ & & $\begin{array}{c}0.256 \\
(11.231)\end{array}$ & & $\begin{array}{l}-14.676 \\
(13.055)\end{array}$ & & $\begin{array}{l}24.288^{*} \\
(13.521)\end{array}$ \\
\hline $\begin{array}{l}\text { Recognized union: } \\
\text { not in } 1990 \text {, in } 1998\end{array}$ & & $\begin{array}{l}-15.048 \\
(9.186)\end{array}$ & & $\begin{array}{c}-7.827 \\
(12.919)\end{array}$ & & $\begin{array}{l}-23.414^{*} \\
(13.591)\end{array}$ \\
\hline Adj. R-squared & 0.2198 & 0.2360 & 0.2878 & 0.2920 & 0.2365 & 0.2721 \\
\hline$F(k, n-k)$ & 4.65 & 4.47 & 2.81 & 2.72 & 2.91 & 3.29 \\
\hline$N$ & & & & & & \\
\hline
\end{tabular}

NOTES: See Wooden and Hawke (Table 4). Survey weights are applied.

Constant term included in each estimation. Variables included in the total sample equations are: employment size in 1990; merger; changed location; autonomy; change in autonomy; single-workplace organization; head office; international market; sector dummies (8); organizational size dummies (2); age of establishment; and private sector. Variables included in the private sector estimation are: employment size in 1990; merger; changed location; autonomy; change in autonomy; single-workplace organization; head office; sector dummies (8); organizational size dummies (2); age of establishment; and international market. Variables included in the public sector estimation are: employment size in 1990; merger; changed location; autonomy; change in autonomy; single-workplace organization; sector dummies (8); organizational size dummies (2); age of establishment; and head office.

Heteroskedastic consistent standard errors in parentheses.

$*, * *, * *$ denote statistical significance at the 0.10 level, 0.05 level, 0.01 level.

SOURCE: 1998 Workplace Employee Relations Panel Survey. 
TABLE 6

CHANGE IN LABOR PRODUCTIVITY AND CHANGE IN FINANCIAL PERFORMANCE:

DESCRIPTIVE STATISTICS

Change in Labor Productivity

$(\%)$

10.7

32.1

57.3

496

NOTE: Data proportions are unweighted

SOURCE: 1998 Workplace Employee Relations Panel Survey.

Improved between 1990 and 1998

Deteriorated between 1990 and 1998
Change in Financial Performance (\%)

21.6

213 
TABLE 7

CHANGE IN LABOR PRODUCTIVITY AND FINANCIAL PERFORMANCE EQUATIONS: ORDERED PROBIT RESULTS

\begin{tabular}{|c|c|c|c|c|c|c|}
\hline & Cha & $\begin{array}{l}\text { abor Prod } \\
\text { al Sample }\end{array}$ & & Chang & $\begin{array}{l}\text { nancial P } \\
\text { tal Samp }\end{array}$ & nance \\
\hline & (1) & $(2)$ & (3) & (4) & $(5)$ & (6) \\
\hline Union & $\begin{array}{c}0.152 \\
(0.271)\end{array}$ & & & $\begin{array}{c}-0.476 \\
(0.331)\end{array}$ & & \\
\hline Union density & $\begin{array}{l}-0.004 \\
(0.004)\end{array}$ & & & $\begin{array}{c}0.006 \\
(0.005)\end{array}$ & & \\
\hline $\begin{array}{l}\text { Recognized union in } \\
1990\end{array}$ & & $\begin{array}{c}-0.388 * * \\
(0.187)\end{array}$ & & & $\begin{array}{l}-0.051 \\
(0.276)\end{array}$ & \\
\hline $\begin{array}{l}\text { Recognized union: } \\
\text { in 1990; in } 1998\end{array}$ & & & $\begin{array}{c}-0.468 * * \\
(0.216)\end{array}$ & & & $\begin{array}{l}-0.192 \\
(0.289)\end{array}$ \\
\hline $\begin{array}{l}\text { Recognized union: } \\
\text { in 1990; not in } 1998\end{array}$ & & & $\begin{array}{l}0.515 * * \\
(0.241)\end{array}$ & & & $\begin{array}{l}0.957^{*} \\
(0.575)\end{array}$ \\
\hline $\begin{array}{l}\text { Recognized union: } \\
\text { not in } 1990 \text {, in } 1998\end{array}$ & & & $\begin{array}{c}0.415 \\
(0.254)\end{array}$ & & & $\begin{array}{c}0.280 \\
(0.373)\end{array}$ \\
\hline Adj. R-squared & 0.0410 & 0.1042 & 0.1184 & 0.0260 & 0.0732 & 0.0894 \\
\hline Wald(k, n-k) & 24.80 & 64.19 & 90.53 & 6.29 & 21.29 & 22.57 \\
\hline$N$ & & 496 & & & 213 & \\
\hline
\end{tabular}

NOTES: See Wooden and Hawke (Table 4). Survey weights are applied.

Constant term included in each estimation. Variables included in equation (1) are as per Table 4, column (2). Variables included in equations (2) and (3) are: employment size in 1990; merger; changed location; autonomy; change in autonomy; single-workplace organization; head office; international market; sector dummies (8); organizational size dummies (2); age of establishment; and private sector.

Heteroskedastic consistent standard errors in parentheses.

$*, * *, * * *$ denote statistical significance at the 0.10 level, 0.05 level, 0.01 level.

SOURCE: 1998 Workplace Employee Relations Panel Survey. 


\section{IZA Discussion Papers}

No. Author(s)

464

465

J. Ermisch

M. Francesconi

466

J. E. Askildsen

E. Bratberg

$\varnothing$. A. Nilsen

467

R. Lalive

J. C. van Ours

J. Zweimüller

470
A. Cigno
F. C. Rosati
L. Guarcello

$471 \quad$ B. R. Chiswick

Y. Liang Lee

P. W. Miller

$472 \quad$ R. Foellmi

J. Zweimüller

473

474

J. T. Addison

L. Bellmann

A. Kölling

475

\section{Z. Hercowitz}

E. Yashiv

476

W. A. Cornelius

T. Tsuda

477

478

479

D. A.

H. Gersbach

A. Schniewind

J. T. Addison

C. R. Belfield

Title

Area

Date

The Hold-Down Problem and the Boundaries of

03/02 the Firm: Lessons from a Hidden Action Model with Endogenous Outside Option

Intergenerational Social Mobility and Assortative $\quad 1$

04/02

Mating in Britain

Unemployment, Labour Force Composition and 1

04/02

Sickness Absence: A Panel Data Study

Are Immigrants Competing with Natives in the

1

Italian Labour Market? The Employment Effect

The Impact of Risk Aversion, Role Models, and the Regional Milieu on the Transition from

Unemployment to Self-Employment: Empirical

Evidence for Germany

The Effect of Benefit Sanctions on the Duration

of Unemployment

04/02

Does Globalisation Increase Child Labour?

2

$04 / 02$

Immigrants' Language Skills and Visa Category

$04 / 02$

Structural Change and the Kaldor Facts of

3

04/02

Economic Growth

A pint a day raises a man's pay, but smoking

5

$04 / 02$

blows that gain away

Unions, Works Councils and Plant Closings in 3

$04 / 02$

Germany

A Macroeconomic Experiment in Mass

04/02

Immigration

Labor Market Incorporation of Immigrants in

04/02

Japan and the United States: A Comparative Analysis

Natives, the Foreign-Born and High School

Equivalents: New Evidence on the Returns to the GED

Uneven Technical Progress and Unemployment

3

$04 / 02$

Unions and Employment Growth: The One

1

$04 / 02$ 